\title{
KRITIK ATAS CORAK PEMIKIRAN TEOLOGI ISLAM K.H. SIRADJUDDIN ABAS
}

\author{
M. Baharudin \\ Insitut Agama Islam Negeri (IAIN) Raden Intan Lampung \\ e-mail: beryyunianto@yahoo.com
}

\begin{abstract}
The article aims to elaborate patterns of theological thought of $\mathrm{KH}$ Siradjuddin Abbas (1905-1980). In the midst of mainstream theological schools established in the Islamic world: traditionalists (Sunni) and rationalists (Mu'tazila), Abbas turns out consistently defend traditional theology. In theological thinking, Abbas positioned parallel to al-Ash'arite classical theology (Ahl al-Sunnah wa IJamä'ah). He stressed all a round of God, revelation paced and use the reason is very little. He put God as absolute ruler, do as His Will. Therefore, theology of Siradjuddin Abbas is very strong hold on revelation and theocentric pattern, and everything begins and centered on God, good or bad all determined by God. Thus theology Siradjuddin Abbas less in line with modern thinking, which is progressive and forward the reason. In other words, theology of Siradjuddin Abbas less actual and contextual for the purposes of contemporary social reality if that expected from such thinking is an applicative conceptual thinking.
\end{abstract}

\begin{abstract}
Abstrak: Artikel ini bertujuan mengelaborasi corak pemikiran teologi K.H. Siradjuddin Abbas (1905-1980). Di tengah mainstream aliran teologi yang sudah mapan di dunia Islam: tradisionalis (Sunni) dan rasionalis (Mu'tazilah), Abbas ternyata konsisten membela teologi tradisional. Dalam pemikiran teologinya, Siradjuddin Abbas sejalan dengan pemikiran teologi klasik al-Asy'ariyah (Ahl alSunnah wa '-Jamä'ah). Ia menekankan segala suatu serba Tuhan, serba wahyu dan sangat sedikit menggunakan akal pikiran. Ia menempatkan Tuhan sebagai berkuasa mutlak semutlak-mutlaknya, berbuat sehendak-Nya. Karena itu, teologi Siradjuddin Abbas sangat kuat berpegang pada wahyu dan bercorak teosentris, dan segalanya bermula dan memusat pada Tuhan, baik atau buruk semua ditentukan oleh Tuhan. Dengan demikian teologi Siradjuddin Abbas yang bercorak tradisional ini kurang sejalan dengan pemikiran modern, yang bersifat progresif dan lebih mengedepankan akal. Dengan kata lain, teologi Siradjuddin Abbas yang bercorak tradisional kurang aktual dan kontekstual untuk keperluan realitas sosial kontemporer jika yang diharapkan dari pemikiran tersebut adalah sebuah pemikiran yang bersifat konseptual aplikatif.
\end{abstract}

Keywords: Sunni; Mu'tazilah; Syafi'iyah; akal; wahyu

\section{A. Pendahuluan}

K.H. Siradjuddin Abbas (lahir di Bengkawas, Kabupaten Agam, Bukittinggi, Sumatera Barat, 20 Mei 1905-meninggal 5 Agustus 1980) adalah seorang ulama, politisi dan pernah menjabat sebagai menteri di Indonesia. Ia dikenal 
sebagai seorang ulama Syafi'iyah dan tokoh utama Perti (Persatuan Tarbiyatul Islamiyah). Salah satu buku K.H. Siradjuddin Abbas yang membahas teologi ialah I'itiqād Ahl al-Sunnah wa 'l-Jamä'ah. Yang lainnya adalah 40 Masalah Agama. Dengan merujuk dua buku ini, sudah tergambar bahwa Siradjuddin Abbas layak dimasukkan ke dalam teolog Indonesia yang mempunyai pengaruh besar, khususnya di kalangan kelompok-kelompok Muslim yang mengklaim sebagai penganut Ahl al-Sunnah wa 'I-Jamä'ah. Meskipun sudah jelas bahwa Siradjuddin Abbas berpaham Ahl al-Sunnah wa 'l-Jamā'ah, namun masih perlu diketahui corak teologinya tersebut dan relevansinya dengan era kontemporer.

Jika selama ini para ahli membagi aliran teologi dalam Islam dalam dua mainstream: aliran tradisional dan rasional, maka di manakah posisi Siradjuddin Abbas. Teologi tradisional menempatkan manusia lebih banyak bersifat pasif, yang tidak sejalan dengan dinamika yang diperlukan perubahan dari yang lama kepada yang baru. Kalau teologinya rasional, akan mempuyai ruang gerak yang lebih luas di bawah paham kebebasan manusia untuk berbuat dan berkehendak dalam batas-batas tertentu, yang dalam istilah Arab dikenal dengan nama Qadariyah. ${ }^{1}$

Bertitik tolak dari uraian di atas, yang menjadi pertanyaannya adalah bagaimana pemahaman K.H. Siradjuddin Abbas tentang teologi Islam dan corak teologinya? Bagaimana kelemahan-kelemahan pemikiran teologinya ketika dihadapkan pada persoalan-persoalan positif-empirik. Melalui pendekatan filsafat dalam menganalisis pemikiran teologi K.H. Siradjuddin Abbas, diharapkan ditemukan detail-detail filosofinya, kemudian dimungkinkan pemikiran tersebut dapat menjadi sebuah alternatif pemikiran teologi di tengah pemikiran teologi yang berkembang di Indonesia.

Kajian terhadap pemikiran K.H. Siradjuddin Abbas, antara lain: (1) Alaiddin Koto (1994)2 , yang mengkaji pemikiran dan perilaku politik K.H. Siradjuddin Abbas. (2) Dani Muhtada (2014) ${ }^{3}$ mengkaji K.H. Siradjuddin Abbas dari aspek 4-5.

${ }^{1}$ Harun Nasution, Muhammad Abduh dan Teologi Rasional Mu'tazilah (Jakarta: UI Press, 1987), h.

${ }^{2}$ Alaiddin Koto, "Pemikiran dan Perilaku Politik K.H. Siradjuddin Abbas." Laporan Penelitian (Pekan Baru: Balai Latihan dan Pengabdian Kepada Masyarakat, Institut Agama Islam Negeri Sulthan Syarif Qasim, 1994).

${ }^{3}$ Dani Muhtada, "Paradigma Hukum Persatuan Tarbiyatul Islamiyah: Analisis Pemikiran Hukum K.H. Siradjuddin Abbas." 2014. Dimuat di http://wwwislamcendekia.com. 
pemikiran hukumnnya. Dalam penelitian Dani Muhtada disebutkan bahwa K.H. Siradjuddin Abbas memiliki sendiri logika-logika hukum yang menempatkannya sebagai seorang ulama Persatuan Tarbiyatul Islamiyah (Perti). Sebagai seorang mujtahid, ia menyandarkan pendapatnya pada naș al-Qur'an dan Hadis dan teori-teori usul fiqh yang diakui validitasnya oleh kalangan ahli hukum Islam. K.H. Siradjuddin Abbas menyandarkan kerangka dasar pendapatnya tetap dalam koridor mazhab Syafi'iyyah, dan ia banyak menukil buku-buku monumental karya ulama dari mazhab ini. (3) Khairil Miswar (2014) ${ }^{4}$ mencoba membandingkan pemikiran K.H. Siradjuddin Abbas dengan Abū Ḥasan al-Ash'arī. la menyimpulkan bahwa Siradjuddin Abbas pada prinsipnya bukanlah pengikut Abū Ḥasan al-Ash'arī, dan dalam beberapa hal Siradjuddin Abbas justru lebih dekat kepada pemahaman Mu'tazilah.

Sejauh pembacaan penelaahaan penulis terhadap studi-studi di atas belum menjawab pertanyaan yang diajukan di atas. Karena itu, kajian ini menjadi signifikan dilakukan.

Penelitian terhadap pemikiran teologi K.H. Siradjuddin Abbas merupakan penelitian pustaka (library research) dengan sumber data utamanya adalah karya-karya yang ditulis oleh K.H. Siradjuddin Abbas, yaitu: (1) Sirāj al-Munïr", (2) Fiqih Syafi'i, (3) Khulasah Tarikh Islami, Sirāj al-Bayān fi Fihrashāt Āyātil Qurān, (4) Sejarah dan Kegamaan Mazhab Syafi'i, (5) I'itiqād Ahl al-Sunnah wa 'Jamä'ah, dan (6) 40 Masalah Agama.

Dalam penelitian ini alat analisis yang digunakan adalah hermeneutika dengan unsur-unsur metode sebagai berikut: (1) Metode deskripsi. Metode ini dimaksudkan untuk mengkaji corak teologi K.H. Siradjuddin Abbas berdasarkan data-data yang telah terkumpul sehingga terbuka kemungkinan relevansi terhadap problematika umat Islam di era kontemporer, khususnya di Indonesia. (2) Metode komparasi. Metode ini dimaksudkan untuk membandingkan pemikiran teologi K.H. Siradjuddin Abbas dengan pemikiran-pemikiran lain, tentang objek penelitian yang akan diteliti dengan realitas problem umat Islam di Indonesia. Tujuannya ialah untuk mengidentifikasi kekuatan dan kelemahan pemikiran teologi tersebut yang hasilnya akan tercermin dalam evaluasi. (3) Metode kesinambungan historis. Dalam hal ini pemikiran teologi K.H. Siradjuddin

${ }^{4}$ Khairil Miswar, "Komparasi Pemikiran Abu Hasan al-Asy'ari dan Siradjuddin Abbas tentang Konsep Istiwa”, 2014. Dimuat di http:// patahkekeringan.blogspot.com 
Abbas dianalisis menurut kerangka historis untuk menunjukkan keberlangsungan dan relevansi baru pemikiran tersebut dalam perkembangan dari dulu sampai sekarang dan akan datang.

Untuk memperoleh hasil analisis yang valid lagi, digunakan pula alat analisis heurestika. Tujuannya adalah untuk menemukan terobosan-terobosan baru, pemikiran-pemikiran dan gagasan-gagasan baru secara ilmiah dari pemikiran K.H. Siradjuddin Abbas dengan demikian dapat dijadikan sebagai pemecahan problem-problem untuk konteks kontemporer. Kemudian disusul langkahlangkah berikutnya dilakukan refleksi secara kritis untuk memperoleh suatu pemahaman yang sistematis, integral, dan holistik, tentang pemikiran teologi K.H. Siradjuddin Abbas. Implikasi dari penetapan metode penelitian ini diharapkan dapat mencapai hasil yang sistematis, terarah, rasional dan maksimal.

\section{B. Pemahaman dan Pengertian Teologi Islam K.H. Siradjuddin Abbas}

Istilah teologi diambil dari khasanah dan tradisi Kristiani. Pemakaian istilah tersebut tidak dimaksud untuk menegasikan arti istilah yang sudah ada pada khasanah Islam. Tidak pula harus dilihat sebagai sesuatu yang negatif, apalagi Islam tersebut dapat memperkaya khasanah dan sistematisasi pemahaman keagamaan. ${ }^{5}$ Secara etimologi teologi berasal dari kata Yunani, yaitu: theos, artinya Tuhan dan logos, yang berarti pengetahuan, yang kemudian diterjemahkan menjadi studi, kajian, telaah, pengetahuan. Jadi, teologi berarti ilmu tentang Tuhan. ${ }^{6}$ Secara terminologi, teologi berarti disiplin yang membahas tentang Tuhan (atau realitas Tuhan) dan hubungan Tuhan dengan alam. ${ }^{7}$ Teologi juga sering dimaksudkan sebagai cabang dari filsafat, yaitu suatu bidang filsafat, yaitu bidang khusus yang mengkaji secara filosofis. ${ }^{8}$

Menurut Kuntowijoyo sampai sejauh ini, perdebatan tentang teologi di kalangan umat Islam berkisar pada tingkat semantik. Mereka yang berlatar

${ }^{5}$ Abdul Aziz Dahlan, Sejarah Perkembangan Pemikiran dalam Islam (Jakarta: Beonebi Cipta, 1980), h. 11.

${ }^{6}$ Vergilius Verm (ed.), An Encylopedia of Relegion (NewYork: Green Press,1976), h. 728.

${ }^{7}$ Adam, D.S., "Theology", dalam James Hastings (ed), Encylopedia of Religion and Ethis,Vol. 12 (New York: Charles Scribner's Sons, t.th.)

${ }^{8}$ Lukman S. Thahir, Studi Islam Interdisipliner: Aplikasi Pendekatan Filsafat, Sosiologi dan Sejarah (Yogyakarta: Qirtas, 2004), h. 104. 
belakang tradisi ilmu ke-Islaman konvensional mengartikan teologi sebagai ilmu kalam, yaitu suatu disiplin yang mempelajari ilmu ketuhanan yang bersifat abstrak, normatif, dan skolastik. Sementara itu bagi mereka yang terlatih dalam tradisi Barat, katakanlah dari cendikiawan Muslim yang tidak mempelajari Islam dari studi-studi formal, lebih melihat teologi sebagai penafsiran terhadap realitas dalam perspektif ketuhanan, yang cenderung refleksi-refleksi empiris. ${ }^{9}$ Yang pertama, lebih menekankan pada kajian ulang mengenai ajaran-ajaran normatif dalam pelbagai karya kalam klasik, sedangkan yang kedua cenderung menekankan perlunya reorientasi pengalaman keagamaan pada realitas kekinian yang empiris. ${ }^{10}$ Dengan kata lain, yang pertama lebih mengajak pada upaya untuk melakukan refleksi-normatif, yang kedua lebih kepada refleksi-aktual dan empiris. Bertolak dari pengertian ini, K.H. Siradjuddin Abbas masuk pada kelompok yang mana?

K.H. Siradjuddin Abbas dalam membahas tentang ketuhanan dan hubungannya dengan alam dan manusia tidak menggunakan istilah teologi Islam. Ia menggunakan istilah ilmu ushuluddin, ilmu kalam, ilmu tauhid, ilmu aqa'id. Menurutnya, di dalam ilmu Ushuluddin dibahas soal-soal i'tiqad yang menjadi pokok bagi agama. Pokok-pokok bagi agama itu mencakup: (1) Kepercayaan (i'tiqād) yang berhubungan dengan Ketuhanan (ilähiyyat); (2) kepercyaan yang berhubungan Kenabian (nubuwwat); (3) Kepercayaan yang berhubungan dengan soal-soal yang ghayb (hari akhirat, surga, neraka, dll); (4) dan lain-lain soal kepercayaan. ${ }^{11}$

Menurut K.H. Siradjuddin Abbas ilmu Ushuluddin kadang-kadang dinamai ilmu kalam, yakni kalam Tuhan, karena dalam ilmu tersebut diperbincangkan sifat-sifat Tuhan, di antarannya sifat kalam (berkata). Ahli ilmu kalam ini dinamai Mutakallimun atau Mutakalimin. Ada juga orang yang menamai ilmu ini dengan ilmu tauhid, yakni ilmu ke-Esaan Tuhan. Ada juga yang menamainya dengan ilmu 'Aqaid, ialah ilmu i'tiqad karena yang diperbincangkan dalam ini ialah persoalan-persoalan i'tiqad (kepercayaan). Di Indoneisa, demikian K.H. Siradjuddin Abbas, ada orang-orang yang menamainya dengan ilmu sifat 20, karena di dalam ilmu tersebut diperbincangkan 20 sifat yang wajib (mesti ada)

${ }^{9}$ Kuntowijoyo, Paradigma Islam Interpretasi untuk Aksi (Bandung: Mizan, 1991), h. 286.

10 Ibid.

${ }^{11}$ K.H. Siradjuddin Abbas, I'tiqad Ahlususunnah wal-Jamaah (Jakarta: Pustaka Tarbiah, 1994), h. 15. 
bagi Tuhan. ${ }^{2}$ K.H. Siradjuddin Abbas kemudian menyimpulkan bahwa istilahistilah ilmu ushuluddin, ilmu kalam, ilmu tauhid, ilmu aqaid, ilmu sifat 20, sama maknanya yaitu ilmu yang memperbincangkan tentang pesoalan-persoalan i'tiqād (kepercayaan tentang ketuhanan, kenabian, dan keakhiratan).

Bertitik tolak dari paparan dan kutipan di atas dapat diketahui bahwa K.H. Siradjuddin Abbas termasuk pemikir yang berlatar belakang tradisi ilmu keIslaman konvensional yang memahami teologi sebagai ilmu kalam yaitu suatu disiplin yang memperbincangkan ilmu Ketuhanan, bersifat abstrak, nurmatif, dan skolastik.

Salah satu titik kelemahan teologi Islam K.H. Siradjuddin Abbas yang paralel dengan teologi Islam klasik Asy'ariyah, adalah masih kentalnya diskursus teologi Islam yang bercorak transendental-spekulatif. Diskursus semacam ini dirasakan terlalu "melangit", bersifat teologis-filosofis, dan terlalu sibuk dengan perdebatan dan wacana yang bersifat ketuhanan-teosentris, hal ini terlihat misalnya ketika K.H. Siradjuddin Abbas memaparkan pemikiran teologinya yang terhimpun dalam karyanya I'itiqād Ahl al-Sunnah wa '-Jamā'ah yang masih berbicara tentang apakah Tuhan itu mempuyai sifat atau tidak? Apakah Tuhan berkehendak mutlak atau terbatas? Apakah al-Qur'an kekal atau baru dan lain sebagainya. Karena persoalan yang diangkat K.H. Siradjuddin Abbas tidak menyentuh aspek kehidupan nyata manusia sehari-hari, seperti masalah demokrasi, kemiskinan, ketidakadilan, dan sederet persoalan lainnya, maka pemikiran-pemikiran teologi K.H. Siradjuddin Abbas dianggap tidak "membumi" atau tidak berdimensi empiris-historis. Ia berbicara tentang Tuhan, di sana atau di "langit", tetapi tidak mengkontekstualisasikan dengan persoalan kemanusian universal sini atau di "bumi".

\section{Corak Pemikiran Teologi Islam K.H. Siradjuddin Abbas}

Berkaitan dengan corak teologi K.H. Siradjuddin Abbas: tradisional atau rasional, memang perlu pengujian lebih lanjut. Untuk itu, penulis akan merujuk pada al-Asy'ariyah (tradisional) dan Mu'razilah (rasional) dengan merujuk pada tema-tema yang menjadi perdebatan kedua aliran ini.

12Ibid., h. 16. 


\section{Akal dan Wahyu}

Persoalan akal ${ }^{13}$ dan wahyu ${ }^{14}$ dalam teologi Islam dibicarakan dalam konteks yang manakah di antara kedua akal dan wahyu, yang menjadi sumber pengetahuan manusia tentang Tuhan, tentang kewajiban, berterima kasih kepada Tuhan, tentang apa yang apa yang baik dan apa yang buruk serta tentang kewajiban menjalankan yang baik dan meninggalkan yang buruk. Aliran teologi Mu'tazilah berpendapat bahwa akal mempuyai kemampuan mengetahui keempat-empat hal tersebut di atas. ${ }^{15}$ Oleh karena itu, wahyu tidak mempuyai fungsi apa-apa dalam keempat hal pokok di atas. Namun tidaklah berarti bahwa wahyu tidak berfungsi sama sekali. Menurut aliran ini, wahyu berfungsi sebagai informatif, menguji, peringatan, konfirmatif dan memperpendek jalan manusia untuk mengetahui Tuhan dan segala yang berkaitan dengan-Nya. ${ }^{16}$ Sementara itu aliran Mātūridiyah Samarkand dan juga termasuk penganut pemikiran teologi rasional mengatakan, kecuali kewajiban menjalankan yang baik dan menghindari yang buruk akal mempuyai kemampuan mengetahui ketika hal lainnya.

Sebaliknya, aliran Asy'ariyah sebagai penganut pemikiran teologi tradisional berpendapat bahwa akal hanya mampu mengetahui Tuhan, sedangkan tiga hal lainnya, yakni kewajiban berterima kasih kepada Tuhan, baik dan buruk serta kewajiban melaksanakan yang baik dan menghindari yang jahat diketahui manusia bedasarkan wahyu. Sementara aliran Mātūridiyah Bukhārā yang juga digolongkan ke dalam pemikiran teologi tradisional berpendapat bahwa dua dari keempat hal tersebut di atas yakni mengetahui Tuhan dan mengetahui yang baik dan yang buruk dapat diketahui dengan akal, sedangkan dua hal lainnya, yakni kewajiban berterima kasih kepada Tuhan serta kewajiban melaksanakan yang baik serta meninggalkan yang buruk dapat diketahui dengan wahyu. ${ }^{17}$ Bagaimana pendapat K.H. Siradjuddin Abbas tentang hal tersebut di atas?

Teologi Mu'tazilah berpendapat bahwa akal dapat mengetahui Tuhan, kewajiban mengetahui Tuhan, baik dan jahat, kewajiban mengerjakan yang baik dan menjahui yang jahat. ${ }^{18}$ Mana yang baik menurut akal baiklah dia dan mana yang

\footnotetext{
${ }^{13}$ Harun Nasution, Akal dan Wahyu dalam Islam (Jakarta: UI Press., 1983), h. 13; A. Hanafi, Pengantar Teologi Islam (Jakarta: Pustaka Al-Husna, 1980), h. 30.

${ }^{14}$ Harun Nasution, Akal dan Wahyu dalam Islam, h. 13.

15Yunan Yusuf, Corak pemikiran Kalam Tafsir Al-Azhar (Jakarta: Panjimas 1990), h. 57.

${ }^{16}$ Harun Nasution, Akal dan Wahyu dalam Islam, h. 98-99.

${ }^{17}$ Harun Nasution, Teologi Islam, Analisa Perbandingan (Jakarta: UI Press, 1972), h. 86.

18Ibid.
} 
buruk menurut akal buruklah dia, demikianlah K.H. Siradjuddin Abbas menjelaskan. Menurut K.H. Siradjuddin Abbas kepercayaan seperti di atas tidak dibenarkan oleh kaum Ahl al-Sunnah wa '-Jamä'ah, karena yang menentukan baik dan buruk itu adalah Tuhan dan rasul-Nya yang terdeskripsi dalam al-Qur'an dan Sunnah bukan akal. Apa yang dikatakan oleh al-Qur'an dan Sunnah maka baiklah ia dan apa yang dikatakan buruk oleh al-Qur'an dan Sunnah buruklah ia. Ditambahkan Siradjuddin Abbas bahwa akal itu digunakan untuk meneliti sebagai instrumen pelaksana, bukan untuk menentukan hukum sesuatu. Yang sebenarnya berhak menentukan hukum-hukum adalah Qur'an dan Sunnah, yang lain tidak. Akal itu diberi kedudukan yang tinggi untuk memahami tiap sesuatu, baik persoalan yang kecil maupun persoalan yang besar, dan bahkan untuk mengetahui wujud-Nya Allah dan sifat-sifat-Nya dipergunakan juga akal pikiran.

Siradjuddin Abbas menandaskan bahwa dalam al-Qur'an banyak sekali ayat yang menyuruh manusia mempergunakan akalnya dan mengajak orang-orang yang tidak mau memakai akalnya. Akan tetapi dalam menetapkan hukum dan menetapkan hal-hal yang terjadi di alam ghaib, semuanya itu hanya ditetapkan oleh syariat dari Tuhan, karena agama itu punya Tuhan bukan punya akal.

Dari paparan di atas menunjukkan bahwa meskipun K.H. Siradjuddin Abbas lebih mengedepankan wahyu daripada akal dalam rangka mendapatkan pengetahuan keagamaan, namun ia tidak melupakan akal dalam memformulasikan pendapat-pendapatnya. Dengan perkataan lain, menurut K.H. Siradjuddin Abbas, dalam mendapatkan pengetahuan tentang agama, wahyu adalah sebagai sumber pengetahuan yang utama, namun demikian ia tidak menegasikan peran akal.

\section{Kebebasan dan Keterpaksaan Manusia}

Persoalan kebebasan dan keterpaksaan manusia ini sudah banyak dikaji oleh para filosof dan para teolog. Di kalangan teolog, aliran teologi rasional Mu'tazilah yang memberikan daya besar kepada akal yang dipunyai manusia, menganut paham kebebasan manusia. Menurut aliran ini manusia mempuyai kebebasan dalam berkehendak dan berkuasa atas perbuatannya. Manusia menciptakn perbuatan-perbuatannya sendiri, berbuat baik dan berbuat buruk, patuh dan tidak patuh kepada Tuhan, adalah atas kehendak dan kemauan manusia itu sendiri. Sedangkan daya untuk mewujudkan kehendak tersebut telah terdapat dalam diri manusia sebelum manusia melakukan perbuatan. ${ }^{19}$

${ }^{19}$ Muhammad ibn 'Abd al-Karīm al-Shahrastanī, al-Milāl wa al-Niḥāl (Kairo: tp., 1951), h. 81. 
Bagi Mu'tazilah daya manusialah dan bukan daya Tuhan yang mewujudkan perbuatan manusia. Daya Tuhan tidak mempuyai bagian dalam perwujudan perbuatan-perbuatan manusia. Perbuatan itu diwujudkan semata-mata oleh daya yang diciptakan Tuhan di dalam diri manusia. Jadi, kemauan dan daya untuk mewujudkan perbuatan manusia adalah kemauan dan daya manusia sendiri dan tak turut campur di dalamnya kemauan dan daya Tuhan. Oleh karena itu perbuatan manusia adalah sepenuhnya perbuatan manusia dan bukan perbuatan Tuhan. Allah tidak mengetahui segala apa pun yang diperbuat manusia. Juga apa yang diberbuat oleh manusia bukanlah qudrat dan bukan iradat Allah. Bahkan manusialah yang mengetahui serta mewujudkan segala yang diamalkannya itu dan semuanya dengan qudrat dan iradat manusia sendiri. Tuhan tidak campur tangan dalam membuktikan amalan-amalan manusia itu. ${ }^{20}$

Di kalangan aliran teologi tradisional Asy'ariyah yang memberikan daya lemah kepada akal manusia, menempatkan manusia pada posisi yang lemah serta banyak bergantung pada kekuasaan dan kehendak mutlak Tuhan. Asy’arī sendiri sebagai tokoh terpenting dalam aliran As'ariyah, dalam menjelaskan persoalan kebebasan dan keterpaksaan manusia ini menampilkan teori al-Kasb (acquisition, perolehan). ${ }^{21} \mathrm{Al}$-Kasb menurut Asy'arī adalah sesuatu yang terjadi dengan perantaraan daya yang diciptakan, atau sesuatu yang timbul dari almuktasib (orang yang memperoleh) dengan perantaraan daya yang diciptakan. ${ }^{22}$ Daya atau kesanggupan itu tidak terwujud sebelum adanya pebuatan. Adanya daya itu bersamaan dengan kegiatan suatu perbuatan. Dengan cara seperti itulah manusia melakukan suatu perbuatan dalam arti tidak menciptakan perbuatan tesebut. Pencipta perbuatan pada hakikatnya adalah Tuhan. Dengan demikian daya manusia kelihata tidak efektif dalam kasb, karena bagaimanapun daya manusia tetap tidak mempuyai efek. Yang efektif dalam perwujudan perbuatan manusia tetap daya dan kemauan Tuhan. Pada akhirnya, manusia tetap ditempatkan Abū Ḥasan al-Ash'arī pada posisi pasif, karena tanpa adanya kemauan dan perbuatan Tuhan, manusia tidak akan mampu mewujudkan perbuatannya.

Sementara itu aliran Mātūridiyah Bukhārā sepaham dengan Mātūridiyah Samarkand, ketika sama-sama mengatakan terdapat dua daya dalam diri

${ }^{20}$ Harun Nasution, Teologi Islam, Analisa Perbandingan, h. 102.

21Yunan Yusuf, Corak pemikiran Kalam Tafsir Al-Azhar, h. 63.

${ }^{2}$ Ibid. 
manusia. Namun Mātūridiyah Bukhārā berbeda dengan Mātūridiyah Samarkand manakala Maturidiah Bukhara ketika mengatakan bahwa manusia tidak mempuyai daya untuk mencipta. Daya yang ada pada diri manusia itu, hanya bisa untuk menjadikan manusia mampu melakukan perbuatannya. Maka dalam hal ini hanya Tuhan yang dapat mencipta dan dalam ciptaan Tuhan itu terdapat perbuatan manusia. Ini berarti manusia hanya dapat melakukan perbuatan yang sudah diciptakan Tuhan bagi dirinya. ${ }^{23}$

Menurut K.H. Siradjuddin Abbas pemikiran-pemikiran teologi rasional Mu'tazilah di atas adalah tidak sesuai dengan ajaran Ahlu al-Sunnah wa alJamā'ah. Menurutnya, yang diimami oleh Imām Abū Ḥasan al-Ash'arī, karena paham ini bertentangan dengan hadis dan al-Qur'an dan tersalah dalam mengambil logika tentang keadilan Tuhan, juga sangat keliru dalam menafsirkan ayat-ayat al-Qur'an. Dalam menolak pandangan Mu'tazilah tentang paham kebebasan dan keterpaksaan manusia itu Siradjuddin Abbas mengemukakan beberapa dalil al-Qur'an di antaranya, pertama: "Dan Tuhan yang menjadikan kamu dan apa yang kamu kerjakan" (QS. al-Ṣâffāt [37]: 96). ${ }^{24}$ Menurut Siradjuddin Abbas, jelaslah dalam ayat ini bahwa yang menjadikan manusia dan yang menjadikan pekerjaan manusia adalah Tuhan, bukan manusia.

Kedua, "Dan kalau mereka mendapatkan kebaikan mereka katakan ini dari Tuhan, dan kalau mereka mendapat bahaya dikatakannya ini dari engkau (hai Muhammad). Katakanlah (kepada mereka): "Semuanya dari Tuhan tetapi kenapa mereka tidak mengerti sesuatu kejadian" (QS. al-Nisā [4]: 78). ${ }^{25}$ Menurut Siradjuddin Abbas hal ini menunjukkan bahwa semua yang buruk-baik dari Tuhan atau sudah dalam takdir Tuhan.

Ketiga, "Allah yang menjadikan segala sesuatu dan Dia Maha Esa dan Maha Perkasa" (QS. al-Ra'd [13]: 16). Nyata dalam ayat ini bahwa yang menjadikan tiap-tiap sesuatu hanyalah Tuhan. Dengan ayat-ayat al-Qur'an di atas terbukalah kebohongan i'tiqād kaum Mu'tazilah/Qadariyah yang menyatakan bahwa semua yang dikerjakan oleh manusia itu adalah atas perbuatan dan kehendak manusia Tuhan tidak campur tangan. ${ }^{26}$

\footnotetext{
23Abd al-Jabbar Ibn Aḥmad, Syarh al-Ușūl al-Khamsah (Kairo: Maktabah Wahbah,1965), h. 107.

${ }^{24}$ K.H. Siradjuddin Abbas, I'tiqad Ahlususunnah wal-Jamaah, h. 232.

${ }^{25}$ Ibid, h. 233.

${ }^{26}$ Ibid,, h. 234.
} 
Sejauh pembacaan penulis terhadap tulisan Siradjuddin Abbas tentang kebebasan dan keterpaksaan manusia, tidak ditemukan argumen-argumen raional yang dilakukannya. Penulis hanya menemukan argumen-argumen tekstual (al-Qur'an). Itupun tidak disertai dengan penjelasan-penjelasan yang luas dan mendasar. Hanya berisi sekedar penolakan terhadap paham pandanganpandangan Mu'tazilah. Karena itu dapat digarisbawahi bahwa Siradjuddin Abbas cenderung mengikuti pemikiran teologi tradisional al-Asy'ariyah.

\section{Sifat-sifat Tuhan}

Mu'tazilah berpendirian Tuhan tidak mempuyai sifat. Satu atribut yang kuat dipertahankan Mu'tazilah adalah ke-Mahaesa-an Tuhan. Tuhan adalah Maha Esa dan Maha Adil dalam usahanya memurnikan paham ke-Mahaesa-an Tuhan. Mereka menolak segala pemikiran yang bisa membawa paham syirik atau politheisme. Jika Tuhan mempuyai sifat, di dalam diri Tuhan terdapat unsur yang banyak; unsur zat dan unsur sifat yang melekat pada zat. Jika Tuhan diatributi 20 sifat berarti Dia tersusun dari 21 unsur; jika 40 sifat, unsurnya akan berjumlah 41; dan jika Dia mempuyai 99 sifat, maka Tuhan terdiri dari 100 unsur. ${ }^{27}$ Pemberian sifat kepada Tuhan akan membawa kepada banyaknya jumlah yang qadim, sedang paham dalam teologi qadim itu esa. Kalau iman dalam ajaran biasa adalah 'tiada Tuhan selain Allah', maka iman dalam teologi adalah 'tiada yang qadim selain dari Allah'. Karena itu paham tentang banyaknya qadìm membawa kepada syirik, dan syirik dalam Islam adalah dosa besar yang tak diampuni Tuhan.

Untuk mengatasi paham syirik inilah, seorang tokoh Mu'tazilah, Wasil mengatakan bahwa Tuhan tidak mempuyai sifat. ${ }^{28}$ Ini tidak berarti bahwa Mu'tazilah menolak ayat-ayat yang menggambarkan sifat-sifat Tuhan seperti alRaḥmān, al-Raḥim, al-Qādir, dan sebagainya. Sebagaimana orang-orang Islam yang percaya bahwa al-Qur'an adalah wahyu yang disampaikan Tuhan kepada Nabi Muhammad, mereka menerima kebenaran ayat-ayat bersama dengan kebenaran seluruh ayat-ayat lainya. Hanya penafsiran mereka tentang ayat-ayat itu berlainan dengan aliran teologi lain dalam Islam. Bagi Mu'tazilah, al-Raḥmān,

${ }^{27}$ Richard C. Martin, dkk, Post-Mu'tazilah: Genealogi Konflik Rasionalisme dan Tradisionalisme Islam, terj. Muhammad Syukri (Yogyakarta: IRCiSoD., 2002), h. 332.

${ }^{28}$ Harun Nasution, Islam Ditinjau dari Berbagai Aspeknya, (Jakarta: UI Press, 1973), h. 38. 
al-Rahīm, al-Qādir, dan sebagainya bukanlah sifat Tuhan tetapi aspek dari zat atau esensi Tuhan. Bagi mereka, Tuhan mengetahui bukan dari sifat pengetahuan, tetapi melalui zat-Nya. ${ }^{29}$ Demikianlah seterusnya dengan ayat-ayat lainya. Tuhan Maha Kuasa dengan kekuasaan dan kekuasaan Tuhan adalah zatNya. Tuhan Maha Pengasih dengan kasih dan kasih Tuhan adalah zat-Nya. Dengan penafsiran serupa ini, Mu'tazilah memberikan gambaran esa kepada diri Tuhan, diri yang tidak disusun dari lapisan zat dan lapisan-lapisan sifat, tetapi dari suatu zat yang mempuyai berbagai aspek. Yang dituju Mu'tazilah dengan peniadaan sifat-sifat adalah pengesaan diri Tuhan, dan dengan demikian menjauhi pengertian politheisme.

Teologi Asy'ariyah tentang sifat-sifat Tuhan berbeda dari Mu'tazilah. Aliran ini berpendapat bahwa Tuhan mempuyai sifat-sifat, seperti sifat mengetahui, hidup, berkuasa, mendengar, melihat, dan lain-lain. Tuhan atau zat Tuhan bukanlah pengetahuan, kehidupan, pendengaran, penglihatan dan sebagainya, tetapi adalah Yang Mengetahui, Yang Hidup, Yang Mendengar, Yang Berkuasa, Yang Melihat, dan seterusnya. Tuhan mustahil mengetahui, mendengar atau melihat dengan zat-Nya. ${ }^{30} \mathrm{Di}$ sini, terkandung pengertian bahwa siat-sifat Tuhan bukanlah zat Tuhan seperti yang dipahami Mu'tazilah. Sifat-sifat adalah sesuatu yang lain dari zat Tuhan. Pemahaman sifat-sifat seperti ini yang ditolak oleh Mu'tazilah.

Tokoh penting aliran tradisional, al-Ash'arī menolak paham anthropomorfisme, yakni paham yang menyatakan bahwa Tuhan mempuyai sifat-sifat jasmani yang sama dengan sifat-sifat jasmani manusia. Ia menegaskan bahwa Tuhan mempuyai dua tangan, tapi itu tidak diartikan rahmat atau kekuasaan Tuhan. Tuhan hidup dengan hayat, yang tidak sama dengan hayat manusia; Ia mempuyai dua tangan yang tidak sama dengan tangan manusia. Tuhan mempuyai mata dan tangan yang tidak dapat diberikan gambar atau definisi. ${ }^{31}$ Selanjutnya al-Ash'arī berpendapat bahwa Tuhan, meskipun bersifat immateri, akan dapat dilihat oleh manusia dengan mata kepala pada hari akhirat. Yang tidak dapat dilihat, menurut al-Ash'arī, hanyalah yang tidak mempuyai wujud.

${ }^{29}$ Richard C. Martin, dkk, Post-Mu'tazilah: Genealogi Konflik Rasionalisme dan Tradisionalisme Islam, h. 333.

${ }^{30} \mathrm{Abū}$ Hasan al-Ash'arī, al-Lumā' fi al-Radd 'ala Ahl al-Zain wa al-Bidā' (Kairo: Syarīkah Musahamah Mișriyah, 1955), h. 30-31.

${ }^{31}$ Abdul Aziz Dahlan, Sejarah Perkembangan Pemikiran dalam Islam, h. 98. 
Yang mempuyai wujud mestilah dapat dilihat; Tuhan berwujud dan karena itu Ia dapat dilihat.

Dalam menanggapi persoalan di atas, Siradjuddin Abbas mengkritik pemikiran-pemikiran Mu'tazilah di atas. Menurutnya, pemikiran tersebut bertentangan dengan paham Ahl al-Sunnah wa 'l-Jamā'ah yang mengatakan bahwa Tuhan mempuyai sifat, bukan satu bukan dua, tetapi banyak. Ada sifat yang mesti (wajib) ada pada Tuhan, ada yang Mustahil (tidak mungkin) ada pada Tuhan dan ada yang harus ada pada Tuhan. Ia merujuk firman Allah: "Dialah Tuhan, tiada Tuhan selain Dia, yang mengetahui yang tersembunyi dan yang terang. Dia Yang Maha Pengasih dan Penyayang" (QS. al-Hashr [59]: 22). Dalam ayat ini jelaslah bahwa ada nama Zat, yaitu Allah (Tuhan) dan ada sifat-Nya yaitu 'Ālim (Yang Mengetahui). ${ }^{32}$

Siradjuddin Abbas merujuk firman Tuhan Allah yang lain; "Dialah Tuhan, yang mengadakan sesuatu, pencipta dan pembentuk rupa" (QS. al-Ḥashr [59]: 24). Menurut K.H. Siradjuddin Abbas, menurut tata bahasa Arab, bahwa alKhāliq, al-Bāri, dan al-Mușawwir adalah sifat bagi Allah.

Tuhan menggambarkan dirinya dalam Qur'an bahwa Ia mempuyai sifat Yang menjadikan, Yang menciptakan, dan Yang membentuk segala rupa. Pendeknya, kalau dibalik ayat-ayat Qur'an akan terdapat banyak sekali yang menyatakan bahwa Tuhan mempunyai sifat. Maka heranlah kita, kenapakah kaum Mu'tazilah berpaham bahwa Tuhan tidak mempuyai sifat? Kaum Mu'tazilah khawatir kalau-kalau Tuhan menjadi dua, yaitu sifat dan zat, yang menghilangkan dasar tauhid-kata mereka. Tidak begitu, kata kaum Ahl alSunnah wa 'I-Jamā'ah. Sifat Tuhan adalah sifat yang qadìm yang berdiri di atas zat yang qadim. Contohnya, dapat dilihat seperti kertas yang ada pada kita. Kertas itu bersifat dengan putih; putih terletak pada kertas. Apakah ada orang berakal didunia yang mengatakan bahwa kertas dan putihnya menjadi dua? Tolol amad orang yang berkata begitu. ${ }^{33}$

Dari penjelasan Siradjuddin Abbas tersebut, tampaklah bahwa sifat Tuhan bertolak belakang dengan paham rasional Mu'tazilah yang menolak Tuhan mempuyai sifat. Karena itu, jelaslah bahwa Siradjuddin Abbas sependapat dengan kaum al-Asy'ariyah, yang mengatakan bahwa Tuhan (Allah) mempuyai sifat.

${ }^{32}$ K.H. Siradjuddin Abbas, I'tiqad Ahlususunnah wal-Jamaah, h. 188.

${ }^{33} \mathrm{Ibid}, \mathrm{h} .188$. 


\section{Pembuat Dosa Besar}

Menurut aliran Mu'tazilah, orang yang berdosa besar bukan kafir dan bukan mukmin, tetapi menduduki posisi antara posisi mukmin dan posisi kafir, yang dikenal dengan al-manzīlah bain al-manzīlatain, posisi menengah. ${ }^{34}$ Menurut Mu'tazilah posisi tertinggi bagi manusia adalah posisi sebagai mukmin, yakni orang mengakui dua kalimat syahadat dan tidak melakukan dosa besar atau melakukan dosa besar tetapi bertobat sebelum wafat; bagi mukmin ini tersedia surga di akhirat. Posisi yang rendah adalah posisi sebagai kafir, yakni orang yang tidak menerima dua kalimat syahadat. Di antara dua posisi di atas terdapat posisi sebagai fāsiq, yakni orang mengakui dua kalimat syahadat, tapi melakukan dosa besar dan tidak bertobat sebelum wafat. Orang ini tidak dapat disebut kafir, karena dia mengakui dua kalimat syahadat dan tidak pula disebut mukmin, karena melakukan dosa besar. ${ }^{35}$

Al-Asy'ariyah menolak konsep dosa besar yang diajukan oleh Mu'tazilah tesebut. Paha mini berpendapat bahwa orang yang berdosa besar tetap mukmin, karena imannya masih ada, tetapi karena dosa besar yang dilakukannya ia menjadi fāsiq. Sekiranya orang berdosa besar bukanlah mukmin dan bukanlah kafir, maka dalam dirinya akan tidak didapati kufur atau iman; dengan demikian bukanlah ia atheis dan bukanlah pula monotheis, tidak teman dan tidak pula musuh. Hal serupa ini tidak mungkin. Oleh karena itu tidak pula mungkin bahwa orang berdosa besar bukan mukmin dan bukan pula tidak kafir. 36

Berkaitan dengan perbedaan pandangan di atas, Siradjuddin Abbas memberi fatwa bahwa pandangan Mu'tazilah tidak sesuai dengan kaum Ahl alSunnah wa 'l-Jamā'ah, karena paham mereka tempat di akhirat hanya dua, kalau tidak surga, neraka. Orang mukmin yang mengerjakan dosa besar dan mati sebelum tobat, maka orang itu tetap mukmin, disembayangkan, dimandikan dan dikuburkan sebagai orang mukmin. Pada hakikatnya ia mukmin yang durhaka pada Tuhan. Orang macam ini menurut keyakinan Ahl al-Sunnah wa 'l-Jamä'ah akan mendapat beberapa kemungkinan:

${ }^{34}$ Harun Nasution, Teologi Islam, Analisa Perbandingan, h. 43.

${ }^{35}$ Abdul Aziz Dahlan, Sejarah Perkembangan Pemikiran dalam Islam, h. 71-72.

36Harun Nasution, Teologi Islam, Analisa Perbandingan, h. 71. 
a. Boleh jadi dosanya diampuni saja oleh Tuhan dengan kemurahan-Nya karena Tuhan itu Pengasih dan Pemurah sesudah itu ia dimaksudkan kedalam surga, tampa hukuman,

b. Boleh jadi ia dapat syafa'at dari Nabi Muhammad; yakni dibantu oleh Nabi Muhammad; sehingga ia dibebaskan Tuhan dan tidak mendapat hukuman dan langsung masuk surga,

c. Kalau yang dua di atas tidak didapat maka ia akan dihukum dan dimasukan ke-dalam neraka buat seketika, dan akhirnya dikeluarkan sesudah menjalani hukuman dan dimasukan ke-dalam surga, kekal selama-lamanya, karena ia orang mukmin pada waktu di dunia. ${ }^{37}$

Ditegaskan oleh Siradjuddin Abbas, inilah ketiga kemungkinan bagi orang mukmin yang kebetulan mengerjakan dosa besar dan tidak taubat sebelum mati. I'tiqād ini bedasarkan ayat-ayat Qur'an dan hadis Nabi. ${ }^{38}$

Ia memperkuat pendapatnya dengan mengutip ayat: "Sesungguhnya Tuhan tidak mengampuni dosa seseorang kalau Ia dipersekutuakan, tetapi diampuniNya selain dari itu bagi siapa yang dikehendaki-Nya. Siapa yang mempersekutukan Tuhan sesungguhnya ia telah memperbuat dosa yang sangat besar."39 Jadi menurut ayat ini siapa saja yang membuat dosa besar-kecil, kalau dosa itu tidak mempersekutukan Tuhan maka ia bisa diampuni oleh yang maha Pengasih dan maha Penyayang. Tidak sebagai pandangan kaum Mu'tazilah yang mengatakan bahwa sekalian pembuatan dosa besar menjadi kafir dan masuk neraka langsung buat selama-lamanya. ${ }^{40}$ Ia juga mengutip hadis: Maka Tuhan berfirman, "Demi kegagahan-Ku, demi kebesaran-Ku, demi ketinggian-Ku, dan demi keagungan-Ku, Aku akan keluarkan dari neraka sekalian orang yang mengucapkan tiada Tuhan yang berhak disembah melainkan Aku"; melalui hadis ini, tegas Siradjuddin Abbas, ada "sekumpulan manusia" yang sesudah kena hukum dalam neraka lalu dikeluarkan lagi dan dimasukkan ke dalam surga. Inilah mereka orang-orang mukmin yang durhaka dengan memperbuat dosa ketika hidupnya. Jadi, orang yang mengerjakan dosa tidak kekal dalam neraka, tetapi akan keluar pada sewaktu-waktu sesudah menjalani hukuman. ${ }^{41}$

\footnotetext{
37K.H. Siradjuddin Abbas, I'tiqad Ahlususunnah wal-Jamaah, h. 195.

${ }^{38} \mathrm{Ibid}$.

${ }^{39}$ QS. al-Nisā’ [4]: 48.

${ }^{40} \mathrm{Ibid}$.

${ }^{41}$ Ibid.
} 


\section{Aktualitas dan Kontekstualitas}

Bertitik tolak dari uraian di atas, jika dicermati secara lebih serius maka pemikiran teologi Siradjuddin Abbas belum terlihat adanya formulasi baru dalam keseluruhan bangunan pemikiran teologinya baik dari aspek substansi maupun epistemologinya. Bahkan secara lugas dapat dikatakan, bahwa tipologi pemikiran teologinya sejalan dengan pemikiran teologi klasik al-Asy'ariyah. Yang mengindikasikan bahwa pemikirannya tersebut belum beranjak dari rumusan-rumusan persoalan teologi Abad Pertengahan, yakni masih berkutat seputar akal dan wahyu, fungsi wahyu, kebebasan dan keterpaksaan manusia, kekuasaan dan kehendak mutlak Tuhan, keadilan Tuhan, perbuatan-perbuatan Tuhan, sifat-sifat Tuhan dan konsep iman, dan lain-lain. Diskursus seperti ini dirasakan terlalu "melangit", bersifat teologi-filosofis, terlalu sibuk dengan perdebatan dan wacana yang bersifat ketuhanan-teoritis. Sebagai seorang intelektual Muslim Indonesia yang hidup pada zaman modern, Siradjuddin Abbas belum mampu melepaskan diri dari keterkungkunganya dalam epistemologi al-Asy'ariyah.

Dalam pandangan penulis - meminjam pernyataan Amin Abdullah dengan mengutip M. Arkoun - seharusnya para pemikir Muslim mulai mencoba untuk beranjak dari pemikiran normatif-spekulatif ke arah pemikiran baru yang kontekstual dan aktual pada zamannya. Ditandai dengan keberanian untuk melepaskan diri dari kungkungan epistemologi masa lalu, 'kalam atau teologi klasik menuju epistemologi baru yang aktual dan kontekstual yang diperlukan oleh realitas sosialitasnya, yang diharapkan akan memunculkan pemikiranpemikiran yang secara substansial dengan zaman.

Keparalelan pemikiran teologi Siradjuddin Abbas dengan pemikiran alAsy'ariyah, misalnya ketika ia mengemukakan pemikirannya tentang persoalan kebebasan dan keterpaksaan perbuatan manusia dan paparannya ketika ia mengelaborasi tentang sifat Tuhan, kedudukan akal, kebebasan dan perbuatan manusia, pembuat dosa besar, dan lain-lain. Dengan mencoba menawarkan tipologi pemahaman tradisionalitasnya yang paralel dengan corak pemikiran klasik al-Asy'ariyah, tampak sekali bahwa pemikiran teologi tradisional tersebut masih mendominasi pemikiran teologi Siradjuddin Abbas.

Dari realitas di atas, aktualitas dan kontekstualitas pemikiran teologi Siradjuddin Abbas dapat disahkan dalam pengertian bahwa pemikiran tersebut berkaitan dengan situasi dan kondisi sosial pada zamannya. Sedang relasinya 
dengan realitas kontemporer yang dirancang bangun oleh Siradjuddin Abbas tetaplah sekedar menjadi wacana pemikiran klasik murni yang kurang actual, karena itu diperlukan adanya sytematic recorntrucsion theology.42 Untuk mengaktualisasikan pemikiran teologi Siradjuddin Abbas dalam rangka melakukan dekonstruksi "atas pemikiran-pemikiran tersebut kemudian dilakukan rekonstruksi systematic yang relevan untuk keperluan zaman. ${ }^{43}$

Bedasarkan pada paparan di atas dapat dipahami bahwa tipologi pemikiran teologi Siradjuddin Abbas kurang aktual dan kontekstual untuk memenuhi kebutuhan zaman, bila yang diharapkan dari pemikiran tersebut adalah sebuah pemikiran yang bersifat konseptual aplikatif. Tetapi sebagai wacana "klasik" pemikiran Siradjuddin Abbas bisa ditempatkan sebagai wacana pemikiran yang aktual dan kontekstual dengan realitas sosial pada zamannya, dalam arti "keperluan" zaman dan situasi dimana pemikiran tersebut dikemukakan berelasi dengan realitas sosial yang memang kondusif untuk menumbuhkan teologi Islam yang berwatak tekstual, normatif, dan cenderung lepas dari konteks historisitasnya. Realitas sosial kontemporer memerlukan pemikiran yang lebih holistik dan apresiasif dalam arti dikonstrutif dan sekaligus rekonstruktif. Karena tanpa keberanian untuk merancang bangun pemikiran yang kontekstual dalam pengertian historis empiris dan aktul, dalam pengertian diperlukan oleh masyarakat dalam realitas sosial pada zamanya, para pemikir akan terjebak pada gerakan pemikiran duplikasi yang secara estaveta mandek dalam subtansi serta metodologinya yang baku. ${ }^{44}$ Oleh karena itu, berdasarkan pemahaman kritis atas pemikiran teologi Siradjuddin Abbas merupakan salah satu wacana pemikiran ke-Islaman yang dapat diapresiasi sebagai warisan pemikiran klasik dengan nuansa klasiknya,dan dapat digunakan sebagai acuan komparatif dalam rangka memperjelas visi pemikiran teologi di masa yang akan datang.

\section{E. Kesimpulan}

Berdasarkan kajian atas aspek-aspek tradisionalitas dan aktualitas dalam pemikiran teologi Islam K.H. Siradjuddin Abbas dapat disimpulkan: Pertama,

42Fazlur Rahman, Islam and Modernity: Transformation of Intellectual Tradition (Chicago: Unversity of Chicago Press., 1982), h. 82.

${ }^{43}$ M. Amin Abdullah, Falsafah Kalam di Era Kontemporer (Yogyakarta: Pustaka Pelajar, 1997), h. 47.

${ }^{44}$ Ibid. 
K.H. Siradjuddin Abbas adalah seorang pemikir Islam Indonesia yang mempuyai latar belakang tradisi ilmu keislaman konfensional, maka K.H. Siradjuddin Abbas mensepadankan teologi dengan ilmu kalam, ilmu ushuluddin, dan ilmu tauhid.

Kedua, dalam pemikiran teologi Islam K.H. Siradjuddin Abbas memang diketahui suatu tipologi teologi tradisional, tradisional yang paralel dengan pemikiran teologi klasik al-Asy'ariyah (Ahl al-Sunnah wa 'l-Jamä'ah). Mereka sama-sama menekankan segala suatu serba Tuhan, serba wahyu dan sangat sedikit menggunakan akal pikiran hal ini ditambah lagi dengan sikap mereka yang menepatkan Tuhan sebagai berkuasa mutlak semutlak-mutlaknya, berbuat sehendak-Nya. Dengan demikian, teologi K.H. Siradjuddin Abbas yang paralel dengan teologi klasik al-Asy'ariyah ini nampak kuat berpegang pada wahyu dan bercorak teosentris, dan segalanya bermula dan memusat pada Tuhan. Baik atau buruk semua ditentukan oleh Tuhan. Dengan demikian memang beralasaan kalau teologi K.H. Siradjuddin Abbas dikategorikan sebagai yang berkarakteristik tradisional, dan kurang sejalan dengan pemikiran modern, yang bersifat proges.

Ketiga, pemikiran teologi Islam K.H. Siradjuddin Abbas yang bercorak tradisional kurang aktual dan konstektual untuk keperluan realitas sosial kontemporer bila yang diharapkan dari pemikiran tersebut adalah sebuah pemikiran yang bersifat konseptual aplikatif tetapi secara wacana 'klasik' pemikiran teologi Islam K.H. Siradjuddin Abbas dapat ditempatkan sebagai wacana pemikiran yang konseptual dengan realitas sosial pada zamanya.]

\section{DAFTAR PUSTAKA}

Abbas, K.H. Siradjuddin, I'tiqad Ahlususunnah wal-Jamaah. Jakarta: Pustaka Tarbiah, 1994.

Abdullah, M. Amin, Falsafah Kalam di Era Kontemporer. Yogyakarta: Pustaka Pelajar, 1997.

Adam, D.S. "Theology", dalam James Hastings (ed), Encylopedia of Religion and Ethis,Vol. 12, New York: Charles Scribner's Sons, t.th.

al-Ash'arī, Abū Ḥasan, al-Lumā' fi al-Radd 'ala Ahl al-Zain wa al-Bidā', Kairo: Syarīkah Musahamah Mișriyah, 1955. 
Dahlan, Abdul Aziz, Sejarah Perkembanagn Pemikiran dalam Islam, Jakarta: Beonebi Cipta, 1980.

Hanafi, A., Pengantar Teologi Islam, Jakarta: Pustaka Al-Husna, 1980.

Ibn Ahmad, 'Abd al-Jabbar, Syarh al-Ușūl al-Khamsah, Kairo: Maktabah Wahbah, 1965.

Koto, Alaiddin, "Pemikiran dan Perilaku Politik K.H. Siradjuddin Abbas", Laporan Penelitian, Pekan Baru: Balai Latihan dan Pengabdian Kepada Masyarakat, Institut Agama Islam Negeri Sulthan Syarif Qasim, 1994.

Kuntowijoyo, Paradigma Islam Interpretasi Untuk Aksi, Bandung: Mizan, 1991.

Martin, Richard C. dkk, Post-Mu'tazilah: Genealogi Konflik Rasionalisme dan Tradisionalisme Islam, terj. Muhammad Syukri. Yogyakarta: IRCiSoD, 2002.

Miswar, Khairil, "Komparasi Pemikiran Abu Hasan Al-Asy'ari dan Siradjuddin Abbas tentang Konsep Istiwa", 2014. Dimuat pada laman http:// patahkekeringan.blogspot.com/

Muhtada, Dani, "Paradigma Hukum Persatuan Tarbiyatul Islamiyah: Analisis Pemikiran Hukum K.H. Siradjuddin Abbas", 2014. Dimuat pada laman http://www.islamcendekia.com.

Nasution, Harun, Teologi Islam, Analisa Perbandingan, Jakarta: UI Press, 1972. Islam Ditinjau Dari Berbagai Aspeknya, Jakarta: UI Press, 1973. Akal dan Wahyu dalam Islam, Jakarta: UI Press, 1983.

Muhammad Abduh dan Teologi Rasional Mu'tazilah, Jakarta: UI Press, 1987.

Rahman, Fazlur, Islam and Modernity: Transformation of Intellectual Tradition, Chicago: Unversity of Chicago Press, 1982.

al-Shahrastanī, Muhammad ibn 'Abd al-Karīm, al-Milāl wa al-Nihāl. Kairo: tp.,. 1951.

Thahir, Lukman S., Studi Islam Interdisipliner: Aplikasi Pendekatan Filsafat, Sosiologi dan Sejarah, Yogyakarta: Qirtas, 2004.

Verm, Vergilius (ed.), An Encylopedia of Relegion, New York: Green Press, 1976.

Yusuf, Yunan, Corak Pemikiran Kalam Tafsir Al-Azhar, Jakarta: Panjimas, 1990.

JURNAL THEOLOGIA — Volume 27, Nomor 2, Desember 2016 
260 JURNAL THEOLOGIA - Volume 27, Nomor 2, Desember 2016 